\title{
АНАЛІЗ ПРОТИПОЖЕЖНИХ ЗАХОДІВ У КОНСТРУКЦІЯХ ЗОВНІШНІХ СТІН ІЗ ФАСАДНОЮ ТЕПЛОІЗОЛЯЦІЮЮ ТА ОПОРЯДЖЕННЯМ ШТУКАТУРКОЮ
}

\author{
Р.С. Яковчук ${ }^{1 *}$, канд. техн. наук, А.Д. Кузик ${ }^{1}$, д-р. с.-е. наук, профресор, О.С. Ємельяненко ${ }^{1}$, \\ канд. техн. наук, Т.М. Скоробагатько ${ }^{2}$ А.І. Івануса ${ }^{1}$, канд. техн. наук, О.В. Добростан ${ }^{2}$, \\ канд. техн. наук \\ ${ }^{1}$ Львівський державний університет безпеки життєдіяльності, Україна \\ 2Український науково-дослідний інститут цивільного захисту, Україна \\ ІНФОРМАЦІЯ ПРО СТАТТЮ \\ Надійшла до редакції: 16.11.2019 \\ Пройшла рецензування: 12.12.2019 \\ КЛЮЧОВІ СЛОВА: \\ теплоізоляція, пінополістирол, \\ енергетична ефективність \\ термомодернізація будівлі, конструкція із \\ фрасадною теплоізоляцією 3 \\ опорядженням штукатуркою, пожежа, \\ протипожежний пояс, мінеральна вата, \\ полімерна штукатурка

\begin{abstract}
АНОТАЦІЯ
Метою роботи $є$ аналіз протипожежних заходів у конструкціях зовнішніх стін із фасадною теплоізоляцією та опорядженням штукатуркою, а також аналіз особливостей їх облаштування, враховуючи досвід інших країн. Розглянуто та проаналізовано види, конструктивні особливості, призначення та функції протипожежних поясів та обрамлення віконних (дверних) прорізів, виконаних 3 негорючих матеріалів, які влаштовуються в конструкціях зовнішніх стін із фасадною теплоізоляцією та опорядженням штукатуркою. Наголошено на значну роль протипожежних поясів та обрамлення віконних (дверних) прорізів із негорючих плит з мінеральної вати у забезпеченні пожежної безпеки будівельних об'єктів. Зроблено висновки про те, що в Україні на національному рівні в нормативних документах процедура облаштування протипожежних поясів та обрамлення навколо віконних та дверних прорізів недостатньо технічно описана (розкрита), що призводить до випадків неправильного трактування цих вимог або взагалі їх нехтування.
\end{abstract}

Bcmyn. Сучасна будівля - це складний комплекс різноманітних інженерних систем, конструкцій i матеріалів, до якого ставляться досить жорсткі вимоги, не лише такі традиційні, як стійкість до зовнішніх дій, естетичність та довговічність, але й нові, що відповідають сучасним уявленням про цілі та завдання будівництва. Серед них, перш за все, виділяють енергетичну ефективність, тобто властивість будівлі, іiі конструктивних елементів, а також інженерного обладнання забезпечувати протягом очікуваного життєвого циклу будівлі побутові потреби людини та оптимальні мікрокліматичні умови для іiі перебування та/або проживання у приміщеннях такої будівлі за нормативно допустимого (оптимального) рівня витрат енергетичних ресурсів на опалення, освітлення, вентиляцію, кондиціонування повітря, гаряче водопостачання 3 урахуванням місцевих кліматичних умов [1]. Вітчизняний та закордонний досвід показує, що пріоритетним і результативним напрямком підвищення енергоефективності будівлі $\epsilon$ додатковий теплозахист огороджуючих конструкцій існуючих будівель [2].

Крім позитивних переваг, роботи 3 термомодернізації можуть збільшувати пожежну навантагу будинків, бо застосування горючого теплоізоляційного матеріалу (у будівельній галузі близько $80 \%$ - це пінополістирол) впливатиме на пожежну небезпеку будівель із фасадною теплоізоляцією [3].

Одним з основних завдань під час будь-якої пожежі $\epsilon$ запобігання поширенню вогню та обмеження поширення токсичних продуктів горіння. Для обмеження поширення пожежі в будинках, згідно $[4,5]$ проектують та встановлюють автоматичні системи протипожежного захисту (автоматичні системи пожежогасіння, системи пожежної сигналізації та протидимного захисту), протипожежні перешкоди, зони, відсіки, тамбур-шлюзи, пояси, розриви тощо. У конструкціях зовнішніх стін із фасадною теплоізоляцією 3 опорядженням штукатуркою, де в якості теплоізоляційного матеріалу використовують теплову ізоляцію групи низької горючості Г1 і групи помірної горючості Г2 (пінополістирол та iн.) та опоряджувальний шар із негорючих матеріалів та матеріалів групи низької горючості Г1, для будівель 3 умовною висотою до 26,5 м включно, обов'язково через кожних три поверхи виконують пояси теплової ізоляції із негорючих матеріалів (наприклад, 3 мінеральної вати) завширшки не менше, ніж дві товщини використаної ізоляції [6]. Такі протипожежні пояси облаштовують по всьому периметру будівлі, крім цього передбачають обрамлення віконних та балконних прорізів також із негорючих матеріалів.

Аналіз останніх досліджень та публікацій. Застосування систем фасадної теплоізоляції не *E-mail: yakovchukrs@ukr.net 
лише покращує теплотехнічні показники огороджувальних конструкцій будівель, забезпечує їх енергетичну ефективність, сприяє вдосконаленню архітектурного вигляду будівель і споруд, але й підвищує їх пожежну небезпеку [7]. Дослідженням проблем пожежної безпеки систем фасадної теплоізоляції, в тому числі й навісних фасадних систем, присвячено низку досліджень [8-20].

В роботі [8] досліджено поширення полум'я поверхнею теплоізоляційних екструдованого пінополістиролу (XPS) та пінополіуретану. Під час проведення експерименту спостерігалися різні явища поширення полум'я, а швидкість виділення тепла використовувалася для аналізу інтенсивності горіння досліджуваних зразків. Висота полум'я представлена як функція виділення тепла (HRR), а також встановлений взаємозв'язок між висотою полум'я та загальним потоком тепла.

В роботах $[9,10]$ авторами також проводилися дослідження поширення полум'я поверхнею плит XPS. Проведено експерименти у лабораторних умовах, під час яких фіксувалися форма полум'я, швидкість поширення вогню, швидкість втрати маси та температура горіння зразків. Зроблено висновки щодо швидкості поширення полум'я, втрати маси, теплопровідності, теплового потоку, а також прискорення поширення полум'я поверхнею горючого теплоізоляційного матеріалу. Експериментальні результати, отримані авторами, узгоджувалися з теоретичним аналізом.

У [11] досліджувався вплив увігнутої структури конструкції фасаду будівлі на поширення полум'я поверхнею екструдованого пінополістиролу. Спостерігалося значне коливання фронту полум'я, при цьому увігнута структура конструкції фасаду сприяла поширенню вогню вгору. Швидкість поширення полум'я збільшується у 0,37 рази зі збільшенням коефіцієнта увігнутої структури фасаду від 0 до 1,6. Розкрито механізм дії увігнутої структури фасаду. Крім того, розроблено модель прогнозування, яка оцінює вплив увігнутої структури на характеристики поширення полум'я поверхнею XPS.

У роботі [12] автор досліджує можливості та шляхи швидкого прихованого поширення вогню в навісній фасадній системі в обхід протипожежних поясів. Такі приховані пожежі можуть поширюватися вертикально або горизонтально на великі та важкодоступні ділянки під облицюванням, тому запобігання поширення вогню у повітряних зазорах $€$ надзвичайно важливим. Автор робить висновок, що протипожежні перешкоди, які найбільш поширені й застосовуються в різних регіонах світу, не можуть в повному обсязі забезпечити запобігання поширення вогню і наголошує на необхідності стандартизації тестування протипожежних бар'єрів у вентильованих фасадних системах.

У роботі [13] представлені результати дослідження «ефекту балкону» на поширення вогню ззовні через вікна поверхнею фасадної системи на верхні поверхи. Для повномасштабних вогневих випробувань використано три конструкції будівлі: 3 вікнами без балкона; 3 балконом та вікнами однакової ширини; 3 балконом на один метр, ширшим за віконний проріз. Результати випробувань також порівняно 3 розрахунковими даними, отриманими за допомогою програмного забезпечення Fire Dynamics Simulator (FDS). Результатом дослідження $\epsilon$ обгрунтування застосування конструкції будівлі з балконом на один метр, ширшим за віконний проріз, як найбільш ефективного для обмеження поширення вогню на розташовані вище поверхи.

Враховуючи великий об'єм досліджень вітчизняних та закордонних науковців, слід відзначити, що на даний час $є$ досить мало праць про особливості влаштування протипожежних поясів з негорючих теплоізоляційних матеріалів у конструкціях зовнішніх стін із фасадною теплоізоляцією 3 опорядженням штукатуркою. Крім цього, актуальною науково-технічною задачею залишається розробка конструктивних рішень для обмеження поширення вогню поверхнею фасадної системи теплоізоляції 3 горючим утеплювачем 3 метою запобігання загибелі або травмування людей під час пожежі, а також мінімізації іiі наслідків.

Постановка проблеми $і$ мета роботи. Влаштування протипожежних поясів 3 негорючих плит з мінеральної вати у конструкціях зовнішніх стін із фасадною теплоізоляцією дають змогу обмежити поширення пожежі або, принаймні, зменшити швидкість поширення вогню поверхнею фасаду. Крім цього, обов'язковою вимогою $\epsilon$ влаштування обрамлення навколо віконних та дверних прорізів 3 негорючих теплоізоляційних матеріалів. Такі протипожежні заходи здатні забезпечити цілісність систем фасадної теплоізоляції під час пожежі, тільки за умови правильного іiі технічного виконання. Використання для цих цілей горючих матеріалів, a також помилки під час проектування та облаштування, значно підвищують рівень пожежної небезпеки будівель із фасадною теплоізоляцією. 
У національних нормативних документах процедура облаштування протипожежних поясів та обрамлення навколо віконних та дверних прорізів недостатньо технічно описана. Нерідко трапляються випадки, коли вимоги нормативних документів щодо влаштування систем фасадної теплоізоляції трактуються неправильно або ж взагалі ігноруються. Це може відбуватися через брак досвіду у виконавців, що здійснюють улаштування фасадів або ж через грубе нехтування ними правил пожежної безпеки 3 метою економії коштів під час будівництва. Тому за мету цієї роботи було поставлено проведення аналізу протипожежних заходів у конструкціях зовнішніх стін із фасадною теплоізоляцією та опорядженням штукатуркою, а також аналізу особливостей їх облаштування, враховуючи досвід інших країн.

Виклад основного матеріалу. Однією 3 найважливіших умов безпечного улаштування сучасних конструкцій зовнішніх стін із фасадною теплоізоляцією та опорядженням штукатуркою $\epsilon$ дотримання вимог пожежної безпеки, які викладені у нормативних документах та технічних умовах. Зокрема, це стосується й влаштування протипожежного пояса, як вузла фасадної системи на межі протипожежних відсіків.

В країнах СС прийнято положення, які визначають способи запобігання можливого поширення вогню під час пожежі в будівлях, які мають конструкцію зовнішніх стін із фасадною теплоізоляцією 3 опорядженням штукатуркою [21]. Ці положення зобов'язують влаштовувати протипожежні пояси із негорючих матеріалів під час виконання утеплення з горючих матеріалів або використовувати негорючий утеплювач у будівлях високого ступеня ризику, в яких проживає або перебуває велика кількість людей, не здатних самостійно евакуюватися у випадку виникнення пожежі (житлові будинки, лікарні, дитячі садки, школи, будинки для людей поважного віку або інші об'єкти 3 масовим перебуванням людей). Аналогічні вимоги прийняті у національних стандартах та будівельних нормах, які передбачають впровадження європейських вимог до енергомодернізації фасадів житлових будинків [6, 22].

Так, згідно 3 [6] у разі застосування у фасадній системі класу А (з опорядженням штукатуркою або дрібно штучними виробами) теплової ізоляції групи низької горючості Г1 і групи помірної горючості Г2 та опоряджувального шару із негорючих матеріалів, та матеріалів групи низької горючості Г1 для будівель $з$ умовною висотою від 9 м до 26,5 м включно, обов'язково необхідно передбачати пояси через кожні три поверхи та обрамлення віконних та балконних прорізів тепловою ізоляцією із негорючих матеріалів завширшки не менше ніж дві товщини використаної ізоляції.

Для фасадних систем класу Б (3 опорядженням індустріальними елементами) 3 шаром теплової ізоляції із негорючих матеріалів, вимоги щодо улаштування протипожежних поясів, віконних та балконних прорізів відсутні.

Для фасадних систем класу В (3 опорядженням прозорими елементами) у разі застосування теплової ізоляції групи низької горючості Г1 при умовній висоті будівлі більше ніж 9 м обов'язково виконують пояси через кожних три поверхи та обрамлення віконних та балконних прорізів тепловою ізоляцією із негорючих матеріалів завширшки не менше ніж дві товщини використаної ізоляції.

Разом 3 тим, у національних будівельних нормах не визначено необхідність облаштування дверних прорізів перших поверхів, внутрішніх кутів зовнішніх стін будівель, вертикальних меж протипожежних відсіків тощо.

У результаті пошуку інформаційних джерел, які містять дані про необхідність та особливості облаштування протипожежних поясів у будівлях, авторами статті проаналізовано методичний посібник [23]. У цьому посібнику наведено рекомендації щодо протипожежних заходів під час улаштування фасадних систем теплоізоляції із зовнішнім декоративно-захисним оздобленням, а також узагальнено та систематизовано інформацію про результати вогневих випробувань, проаналізовано фактори, які визначають умови безпечної експлуатації будівель, обладнаних системами фасадної теплоізоляції, а також наведено приклади конструктивних рішень фасадних систем та влаштування в них протипожежних поясів, які виконані із негорючих матеріалів. Крім того, в посібнику зазначено, що конструкції фасадних систем теплоізоляції, які застосовуються в будівлях, мають не поширювати вогонь поверхнею, а проектування таких систем повинно виконуватися для конкретної будівлі 3 урахуванням особливостей об'ємнопланувальних і конструктивних рішень.

Відповідно для попередження масштабів пожеж фасадів із полімерними утеплювачами та опорядженням штукатуркою розглядають наступні спеціальні заходи [23]:

- по периметру віконних, балконних та вентиляційних прорізів облаштування протипожежних поясів із негорючих плит 3 мінеральної вати густиною не менше $120 \mathrm{\kappa} / \mathrm{m}^{3}$. 
Ширина таких поясів повинна становити не менше 150 мм, висота (товщина) не менше загальної товщини плити, яка застосовується для утеплення (рис. 1);

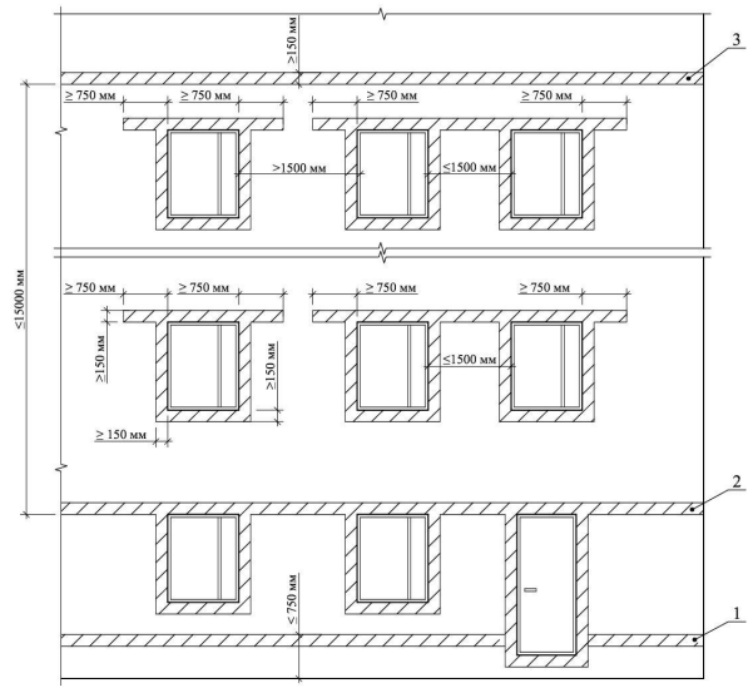

1 - на рівні цокольного поверху; 2 - на 1-му поверсі; 3 - на наступних поверхах

Рисунок 1 - Схема облаштування протипожежних поясів по периметру будівлі та навколо віконних прорізів

- облаштування відкосів із негорючих плит 3 мінеральної вати шириною не менше 1 м по периметру евакуаційних виходів з будівлі (рис. 2);

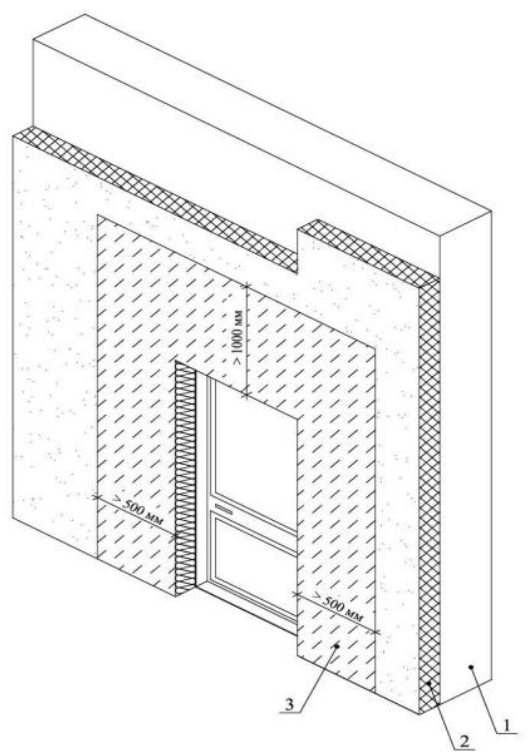

1 - несуча стіна; 2 - горюча теплоізоляційна плита; 3 - протипожежне обрамлення із негорючих матеріалів (мінеральної вати)

Рисунок 2 - Схема облаштування відкосів 3 мінеральної вати шириною не менше 1 м по периметру евакуаційного виходу з будівлі

- облаштування по периметру фасаду будівлі горизонтальних і вертикальних протипожежних поясів із негорючих плит 3 мінеральної вати, як правило через кожні три поверхи (рис. 3);

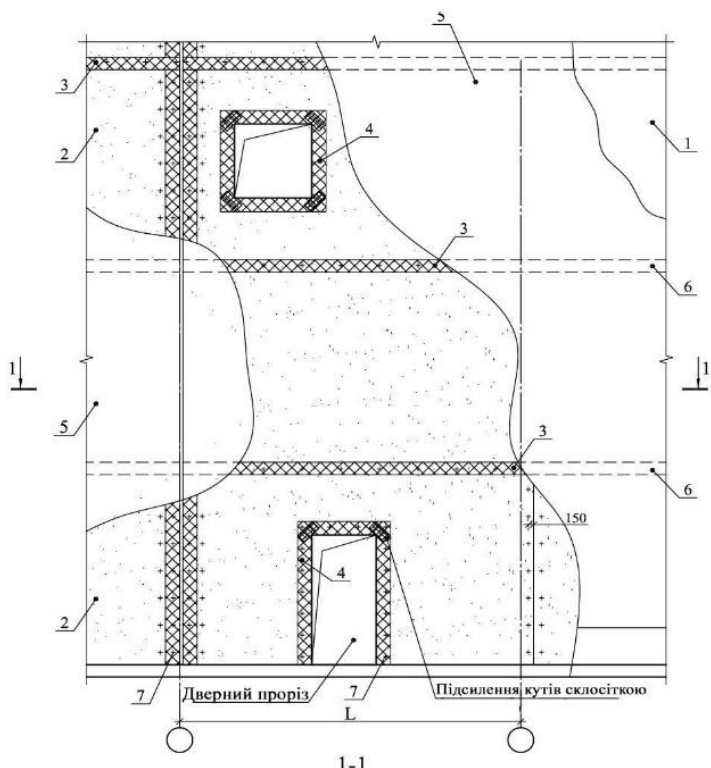

1 - несуча стіна; 2 - горюча теплоізоляційна плита; 3 - протипожежні пояси із негорючих матеріалів (мінеральної вати); 4 - обрамлення віконних та дверних прорізів із негорючих матеріалів; 5 зовнішній оздоблювально-захисний шар; 6 - плита перекриття; 7 - елементи кріплення теплоізоляційної плити (дюбеля)

Рисунок 3 - Схема облаштування горизонтальних та вертикальних протипожежних поясів системи фасадної теплоізоляції з горючим утеплювачем

- облаштування протипожежних поясів із застосуванням в якості утеплювача негорючих плит з мінеральної вати у внутрішніх кутах будівлі за наявності віконних прорізів (рис. 4);

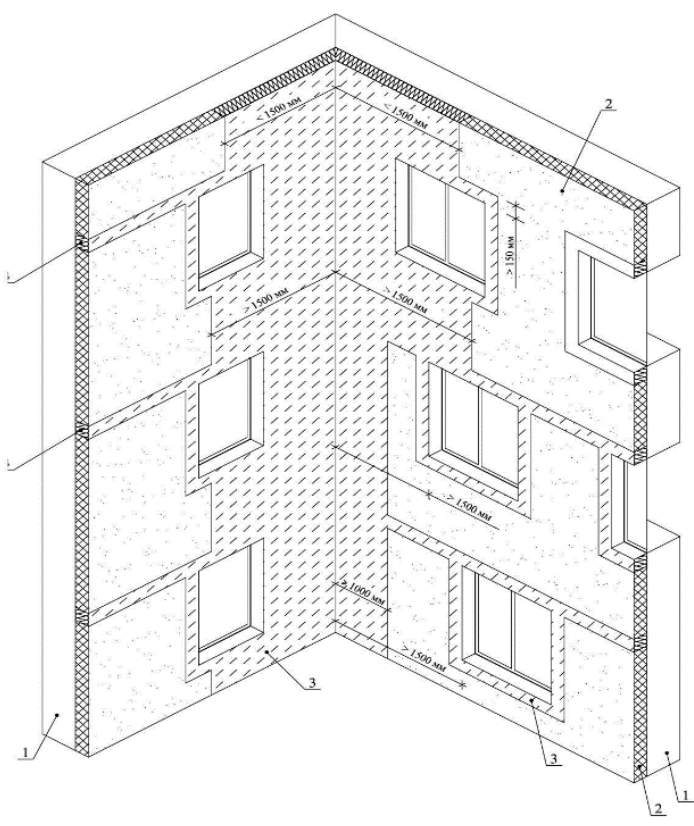

1 - несуча стіна; 2 - утеплювач з горючого матеріалу; 3 - плита 3 негорючої мінеральної вати Рисунок 4 - Схема облаштування протипожежних поясів у внутрішніх кутах будівлі за наявності віконних прорізів 
Відповідно до [23] поверхові протипожежні пояси та обрамлення віконних (дверних) прорізів із негорючих плит 3 мінеральної вати відіграють важливу роль у забезпеченні пожежної безпеки будівлі, яка полягає в наступному:

- зазначені протипожежні пояси та обрамлення забезпечують кріплення оздоблювально-захисного шару штукатурки конструкції фасадної теплоізоляції будівлі під час тепловії дії пожежі;

- наявність горизонтальних поверхових протипожежних поясів перешкоджає поширенню горючих газів, нагрітих до високих температур всередину системи теплоізоляції. Це виключає можливість процесу усадки пінополістиролу всередині фасадної системи;

- обрамлення віконного прорізу приміщення, 3 якого поширюється полум'ям, перешкоджає прогріванню пінополістиролу до температури початку термодеструкції, обмежуючи таким чином можливість потрапляння горючих газів у факел пожежі;

- протипожежні пояси та обрамлення віконних (дверних) прорізів 3 мінеральної вати забезпечують цілісність конструкцій зовнішніх стін із фасадною теплоізоляцією та опорядженням штукатуркою під час виникнення пожежі за умови правильного виконання робіт з їх облаштування.

Якщо ж в конструкції фасадної теплоізоляції 3 горючим утеплювачем не будуть передбачені

\section{СПИСОК ЛІТЕРАТУРИ}

1. ДБН В.2.6-31:2016 Теплова ізоляція будівель. Вид. офіц. Київ: Державне підприємство «Укрархбудінформ». 2016. $37 \mathrm{c}$.

2. Ратушняк О.Г. Управління змістом інноваційних проектів термомодернізації будівель: Монографія. - Вінниця: УНІВЕРСУМ-Вінниця, 2010. - $114 \mathrm{c}$.

3. Кузиляк В.Й., Яковчук Р.С., Веселівський Р.Б. Пожежна небезпека використання пінопоістиролу як теплоізоляційного матеріалу у будівництві. Пожежна безпека: Зб. наук. праць. 2016. (№27). С. 81-87.

4. ДБН В.1.1-7-2016 Пожежна безпека об'єктів будівництва. Загальні вимоги. Вид. офіц. Київ: Міністерство регіонального розвитку, будівництва та житловокомунального господарства України. 2016. 39 с.

5. ДБН В.2.5-56:2014 Системи протипожежного захисту. Вид. офіц. Київ: Міністерство регіонального розвитку, будівництва та житлово-комунального господарства України. 2015. $133 \mathrm{c.}$

6. ДБН В.2.6-33:2018 Конструкції зовнішніх стін із фасадною теплоізоляцією. Вимоги до проектування. Вид. офіц. Київ: Державне підприємство «Укрархбудінформ». 2018. $22 \mathrm{c}$.

7. Яковчук Р., Кузик А., Міллер О., Лин А. Теплоізоляційнооздоблювальні системи фасадів будинків як фактор підвищеної пожежної небезпеки. Пожежна безпека. 32 (Cеp 2018), 80-89. https://doi.org/https://doi.org/10.32447/20786662.32.2018.12

8. Hou, Yanan \& Cheng, Xudong \& Liu, Shenyou \& Liu, Changcheng \& Zhang, Heping. (2015). Experimental Study on upward Flame Spread of Exterior Wall Thermal Insulation елементи 3 негорючої мінеральної вати, тоді пожежна небезпека таких конструкцій суттєво підвищується, особливо за умови використання в оздоблювально-захисному шарі полімерних штукатурок [23].

Перелічені вище протипожежні заходи, що передбачаються у конструкціях зовнішніх стін із фасадною горючою теплоізоляцією, перш за все призначені для забезпечення необхідного часу безпечної евакуації людей з будівлі, недопущення поширення пожежі на весь периметр будівлі та забезпечення безпечної роботи персоналу пожежно-рятувальних підрозділів [24].

Висновки. Визначено конструктивні параметри облаштування протипожежних поясів і обрамлення віконних та балконних прорізів, за якими забезпечується обмеження поширення вогню по фасаду будинків і споруд під час пожежі. Показано, що периметр будівлі, а також віконні, балконні та вентиляційні прорізи необхідно облаштовувати протипожежними поясами 3 негорючих плит з мінеральної вати завширшки не менше ніж дві товщини використаної теплової ізоляції, при чому їх облаштування може бути як горизонтальне так i вертикальне; периметр евакуаційних виходів 3 будівлі - поясами шириною не менше 1 м. Також необхідно облаштовувати зазначеними плитами внутрішні кути будівлі за наявності в них віконних та балконних прорізів.

Materials. Energy Procedia. 66. 161-164. https://doi.org/10.1016/j.egypro.2015.02.085

9. Zhang, Y., Huang, X., Wang, Q., Ji, J., Sun, J., \& Yin, Y. (2011). Experimental study on the characteristics of horizontal flame spread over XPS surface on plateau. Journal of Hazardous Materials, 189(1-2), 34-39. https://doi.org/10.1016/j.jhazmat.2011.01.101

10. An, W. \& Xiao, Huahua \& Sun, Jinhua \& Liew, K. \& Yan, W. \& Zhou, Y. \& Jiang, Lin \& Huang, Xinjie. (2014). Effects of Sample Width and Sidewalls on Downward Flame Spread over XPS Slabs. Fire Safety Science. 11. 234-247. DOI: 10.3801/IAFSS.FSS.11-234

11. An, W., Sun, J., Liew, K. M., \& Zhu, G. (2017). Effects of building concave structure on flame spread over extruded polystyrene thermal insulation material. Applied Thermal Engineering, 121, 802-809. https://doi.org/10.1016/j.applthermaleng.2017.04.141

12. Jensen G. Fire spread modes and performance of fire stops in vented facade constructions - overview and standardization of test methods // Matec web of conference 9. 2013. pp. 1-11. https://doi.org/10.1051/matecconf/20130902002

13. Morgado, H. and Rodrigues, J. (2015), "Balcony Effect on the External Fire Spread into Upper Floors", Journal of Structural Fire Engineering, Vol. 6 No. 4, pp. 255-274. https://doi.org/10.1260/2040-2317.6.4.255

14. Sun, H., Pan, Y., Wang, J. H., Gong, J. H., Ding, A. P., \& Jiang, J. C. (2018). Flame Spread Characteristics of Inclined Extruded Polystyrene Thermal Insulation Material. In Procedia Engineering (Vol. 211, pp. 651-658). Elsevier Ltd. https://doi.org/10.1016/j.proeng.2017.12.060 
15. Suzanne, Mathieu \& Ukleja, Sebastian \& Delichatsios, M. \& Zhang, Jianping \& Karlsson, B.. (2014). Fundamental flame spread and toxicity evaluation of fire retarded polymers. Fire Safety Science, Vol. 11, 2014, p. 846-859. https://doi.org/10.3801/IAFSS.FSS.11-846

16. Косачев А.А. Анализ пожарной опасности навесных фасадных систем в реконструируемых зданиях // Пожаровзрывобезопасность. 2012. № 11 (21). С. 77-80.

17. Samar E. Y., Onokhov O.V., Holupova A.P. Fire safety study of buildings shed-governmental facades // Far East: Problems Of Architectural Complex. 2013. № 1. pp. 357-362.

18. Мешалкин Е.А. Пожарная безопасность навесных вентилируемых фасадов // Пожарная безопасность в строительстве. 2011. № 3. 40-47.

19. Молчадский И.С., Зигерн-Корн В.Н. Фасадные теплоизоляционные системы. Особенности пожарной опасности навесных систем с воздушным зазором // Пожарная безопасность. 2008. № 2. 56-60.

20. Ламкин О.Б., Гравит М.В., Недрышкин О.В. Экспериментальные и теоретические исследования

\section{REFERENCES}

1. DBN V.2.6-31:2016 Thermal insulation of buildings. (2016). Kiev: "Ukrarkhbudinform" (in Ukr.)

2. Ratushnyak O. (2010). Content management of innovative thermo-modernization projects for buildings: Monograph. $114 \mathrm{p}$.

3. Kuzyliak, V., Yakovchuk, R., \& Veselivskyi, R. (2016). Fire risk of thermal insulation materials using in building industry. Fire Safety, 28, 81-87 (in Ukr.)

4. DBN V.1.1-7:2016 Fire safety objects of construction. General requirements. (2016). Kiev: Ministry of Regional Development, Construction and Housing and Communal Services of Ukraine (in Ukr.)

5. DBN V.2.5-56:2014 Fire protection systems. (2014). Kiev: Ministry of Regional Development, Construction and Housing and Communal Services of Ukraine (in Ukr.)

6. DBN V.2.6-33:2018 Constructions of heat insulated external walls. Requirements for the designing. (2018). Kiev: "Ukrarkhbudinform" (in Ukr.)

7. Yakovchuk, R., Kuzyk, A., Miller, O., \& Lyn, A. (2018). Heat insulation-apparatus systems of household facade as a factor of increased fire hazard. Fire Safety, (32), 80-89. https://doi.org/https://doi.org/10.32447/20786662.32.2018.12

8. Hou, Yanan \& Cheng, Xudong \& Liu, Shenyou \& Liu, Changcheng \& Zhang, Heping. (2015). Experimental Study on upward Flame Spread of Exterior Wall Thermal Insulation Materials. Energy Procedia. 66. 161-164. https://doi.org/10.1016/j.egypro.2015.02.085

9. Zhang, Y., Huang, X., Wang, Q., Ji, J., Sun, J., \& Yin, Y. (2011). Experimental study on the characteristics of horizontal flame spread over XPS surface on plateau. Journal of Hazardous Materials, 189(1-2), 34-39. https://doi.org/10.1016/j.jhazmat.2011.01.101

10. An, W. \& Xiao, Huahua \& Sun, Jinhua \& Liew, K. \& Yan, W. \& Zhou, Y. \& Jiang, Lin \& Huang, Xinjie. (2014). Effects of Sample Width and Sidewalls on Downward Flame Spread over XPS Slabs. Fire Safety Science. 11. 234-247. DOI: 10.3801/IAFSS.FSS.11-234

11. An, W., Sun, J., Liew, K. M., \& Zhu, G. (2017). Effects of building concave structure on flame spread over extruded polystyrene thermal insulation material. Applied Thermal Engineering, 121, 802-809. https://doi.org/10.1016/j.applthermaleng.2017.04.141

12. Jensen G. Fire spread modes and performance of fire stops in vented facade constructions - overview and standardization of test methods // Matec web of conference 9. 2013. pp. 1-11. https://doi.org/10.1051/matecconf/20130902002 показателей пожарной опасности фасадной системы «Техноком» // СУЗИС. 2015. № 11 (38). С. 49-65.

21. M. J. Rukavina, M. Carević, I.P. Banjad. (2017). Zaštita pročelja zgrada od požara - Priručnik za projektiranje i izvođenje. 2017. 65 p.

22. ДСТУ Б В.2.6-36:2008 Конструкції будинків і споруд. Конструкції зовнішніх стін із фасадною теплоізоляцією та опорядженням штукатурками. Загальні технічні умови. Вид. офіц. Київ: Мінрегіонбуд України. 2009. 35 с.

23. Противопожарные мероприятия при проектировании фасадных систем. (Методическое пособие). - М.: ФГБУ ВНИИПО МЧС России. 2017. 148 с.

24. Яковчук Р., Кузик А., Смельяненко С., Скоробагатько Т. Механізм поширення пожежі поверхнею конструкцій зовнішніх стін із фасадною теплоізоляцією 3 горючим утеплювачем та опорядженням штукатуркою. Пожежна безпека. 34 (Лип 2019), 96-103.

https://doi.org/https://doi.org/10.32447/20786662.34.2019.16.

13. Morgado, H. and Rodrigues, J. (2015), "Balcony Effect on the External Fire Spread into Upper Floors", Journal of Structural Fire Engineering, Vol. 6 No. 4, pp. 255-274. https://doi.org/10.1260/2040-2317.6.4.255

14. Sun, H., Pan, Y., Wang, J. H., Gong, J. H., Ding, A. P., \& Jiang, J. C. (2018). Flame Spread Characteristics of Inclined Extruded Polystyrene Thermal Insulation Material. In Procedia Engineering (Vol. 211, pp. 651-658). Elsevier Ltd. https://doi.org/10.1016/j.proeng.2017.12.060

15. Suzanne, Mathieu \& Ukleja, Sebastian \& Delichatsios, M. \& Zhang, Jianping \& Karlsson, B.. (2014). Fundamental flame spread and toxicity evaluation of fire retarded polymers. Fire Safety Science, Vol. 11, 2014, p. 846-859. https://doi.org/10.3801/IAFSS.FSS.11-846

16. Kosachev A. A. Analiz pozharnoy opasnosti navesnykh fasadnykh sistem $\mathrm{v}$ rekonstruiruyemykh zdaniyakh [Fire risk in SFS] // Pozharovzryvobezopasnost. 2012. № 11 (21). S. 7780.

17. Samar E. Y., Onokhov O.V., Holupova A.P. Fire safety study of buildings shed-governmental facades // Far East: Problems Of Architectural Complex. 2013. № 1. pp. 357-362.

18. Meshalkin Ye. A. Pozharnaya bezopasnost navesnykh ventiliruyemykh fasadov // Pozharnaya bezopasnost v stroitelstve. 2011. № 3. 40-47.

19. Molchadskiy I. S., Zigern-Korn V. N. Fasadnyye teploizolyatsionnyye sistemy. Osobennosti pozharnoy opasnosti navesnykh sistem s vozdushnym zazorom // Pozharnaya bezopasnost. 2008. № 2. 56-60.

20. Lamkin O. B., Gravit M. V., Nedryshkin O. V. Eksperimentalnyye i teoreticheskiye issledovaniya pokazateley pozharnoy opasnosti fasadnoy sistemy «Tekhnokom» // SUZIS. 2015. № 11 (38). S. 49-65.

21. M. J. Rukavina, M. Carević, I.P. Banjad. (2017). Zaštita pročelja zgrada od požara - Priručnik za projektiranje i izvođenje. 2017. $65 \mathrm{p}$.

22. DSTU B V. 2.6-36:2008 Construction of buildings and structures. Construction of the external walls with facade insulations and plaster. General technical requirements (2009), Kiev: Minrehionbud (in Ukr.)

23. Fire-prevention measures in the design of facade systems (Toolkit). - M .: FSBI VNIIPO EMERCOM of Russia. 2017. $148 \mathrm{p}$.

24. Yakovchuk, R., Kuzyk, A., Yemelyanenko, S., \& Skorobagatko, T. (2019). Fire spread mechanism on surface of construction fit with façade heat insulation based on combustible insulant and finished with plaster. Fire Safety, (34), https://doi.org/https://doi.org/10.32447/20786662.34.2019.16 


\section{ANALYSIS OF FIRE-FIGHTING MEASURES IN CONSTRUCTION OF EXTERIOR WALLS FIT WITH FAÇADE HEAT INSULATION AND FINISHED WITH PLASTER R. Yakovchuk ${ }^{1}$, Cand. of Sc., A. Kuzyk ${ }^{1}$, Doct. of Sc., S. Yemelyanenko ${ }^{1}$, Cand. of Sc., T. Skorobagatko', A.Ivanusa', Cand. of Sc., O. Dobrostan', Cand. of Sc. \\ ${ }^{1}$ Lviv State University of Life Safety, Ukraine \\ ${ }^{2}$ The Ukrainian Civil Protection Research Institute, Ukraine}

\section{KEYWORDS}

thermal insulation, polystyrene, energy efficiency, thermo-modernization of the building, construction with facade thermal insulation with plaster equipment, fire, fire zone, mineral wool, polymer plaster

\begin{abstract}
ANNOTATION
The purpose of the work is to analyze fire prevention measures in structures of external walls with facade thermal insulation and plastering, as well as to analyze the features of their arrangement, taking into account the experience of neighboring countries. The application of exterior wall designs with facade thermal insulation with plaster finish, as well as problems related to their fire hazard, are substantiated. The works are analyzed to investigate the problems of fire safety of exterior wall structures with facade thermal insulation and plastering, as well as hinged facade systems. The types, design features, purpose and functions of fire belts and framing of window (door) openings made of non-combustible materials, which are arranged in exterior wall designs with facade thermal insulation and plaster finish, are considered and analyzed. The role of floor fire belts and the framing of window (door) openings made of non-combustible mineral wool boards have been established.

It is concluded that the use of structures of the exterior walls of residential buildings with facade thermal insulation with a combustible insulation and plastering significantly increases their level of fire danger. This danger will depend both on the properties of the individual materials (in particular the insulation), and on the design features of the entire thermal insulation system and the building as a whole. For plaster systems of thermal insulation of facades, the rapid spread of fire on the higher and lower floors of the building is a big threat. Frequent causes of fire of thermal insulation systems of external walls is the tipping of fire from a window opening of a building as a result of intense fire indoors. Materials of decorative and protective finishing of walls should meet requirements of normative documents on designs of external walls with facade thermal insulation and plaster finish, and their constructive execution will depend on the height of the building and functional purpose of the object. Fire-fighting measures, foreseeing in the construction of exterior walls with facade thermal insulation and plastering, intended to ensure their fire safety during the time necessary for the safe evacuation of people from the building, the arrival of units of fire and rescue units and extending the fire throughout its distribution.
\end{abstract}

\section{АНАЛИЗ ПРОТИВОПОЖАРНЫХ МЕРОПРИЯТИЙ В КОНСТРУКЦИЯХ ВНЕШНИХ СТЕН С ФАСАДНОЙ ТЕПЛОИЗОЛЯЦИЕЙ И ОТДЕЛКОЙ ШТУКАТУРКОЙ}

Р.С. Яковчук ${ }^{1}$, канд. техн. наук, А.Д. Кузик ${ }^{1}$, д-р. сельскохозяйственных наук, профрессор,

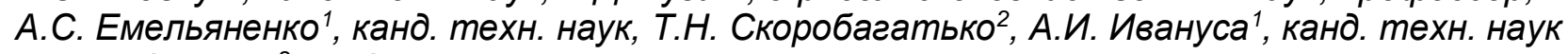
А.В. Добростан ${ }^{2}$ канд. техн. наук

1Львовський государственный университет безопасности жизнедеятельности, Украина

гУкраинский научно-исследовательский институт гражданской защиты, Украина

\section{КЛЮЧЕВЫЕ СЛОВА}

теплоизоляция, пенополистирол,
энергетическая эффективность,
термомодернизация здания,
конструкция с фасадной
теплоизоляцией с отделкой
штукатуркй, пожар, противопожарный
пояс, минеральная вата, полимерная
штукатурка

\section{АННОТАЦИЯ}

Целью работы является анализ противопожарных мероприятий в конструкциях наружных стен с фасадной теплоизоляцией и отделкой штукатуркой, а также анализ особенностей их устройства, учитывая опыт других государств. Рассмотрены и проанализированы виды, конструктивные особенности, назначение и фрункции противопожарных поясов и обрамления оконных (дверных) проемов выполненных из негорючих материалов, которые устраиваются в конструкциях наружных стен с фасадной теплоизоляцией и отделкой штукатуркой. Установлена роль этажных противопожарных поясов и обрамления оконных (дверных) проемов из негорючих плит из минеральной ваты. Сделаны выводы о том, что в Украине, в национальных нормативных документах процедура обустройства противопожарных поясов и обрамление вокруг оконных и дверных проемов, недостаточно технически описана. В силу этого обстоятельства возможны случаи, когда требования нормативных документов по устройству систем фрасадной теплоизоляции трактуются неправильно или вообще игнорируются. 